УДК 378.1:316.7

DOI: 10.37026/2520-6427-2021-107-3-60-64

\author{
Олена БУЧКОВСЬКА, \\ кандидат культурології, \\ доцент кафедри документальних комунікацій \\ та бібліотечної справи \\ Рівненського державного \\ гуманітарного університету, \\ м. Рівне, Украӥна \\ ORCID: 0000-0001-9901-0337 \\ e-mail:anella.anella77@gmail.com
}

\section{Олена ВЕРЕМЧУК,}

кандидат педагогічних наук, доцент кафедри філологічних дисичилін та соиіальних комунікацій

Мукачівського державного університету, м. Мукачево, Украӥна

ORCID: 0000-0003-2514-8733

e-mail: overemchukpopchuk@gmail.com

\title{
МУЛЬТИКУЛЬТУРНИЙ ПІДХІД ДО ПРОФЕСІЙНОЇ ПІДГОТОВКИ ФАХІВЦІВ У ЗАКЛАДІ ВИЩОЇ ОСВІТИ
}

Анотація. Стаття присвячена проблемі мультикультурної освіти, щчо стала глобальною необхідністю, спеціалізованою формою навчання, котра трунтується на позиціях рівності, плюралізму, визнання та прийняття різноманіття соиіокультурного середовища. Мультикультурний підхід до вищої освіти вимагає переосмислення сутності та переформатування змісту навчального прочесу. Культурна стратегія розвитку закладів вищеӧ освіти має бути орієнтованою на організацію мультикультурного освітнього середовища, у якому відбувається формування мультикультурної особистості студента. Включення дисииилін мультикультурного дискурсу дозволить набувачам вищої освіти здобути знання щчодо моральних иінностей інших культур, розширити можливості професійного зростання та отримання досвіду в інших країнах. Мультикультурна освіта у статті розглядається як об'єктивна потреба сучасного суспільства у підготовиі культурно-компетентнісного фахівия, який поряд з академічними та професійними знаннями повинен отримувати знання та навички міжкультурних взаємовідносин, культурного плюралізму, здатності жити та працювати у культурно різноманітних суспільствах.

Ключові слова: мультикультурна освіта, вища освіта, мультикультурне середовище, навчальний процес, онлайн-навчання.

\author{
Olena BUCHKOVSKA, \\ Ph.D in Philosophy, \\ Associate Professor at the Department of \\ Documentary Communications and Library Science, \\ Rivne State Humanitarian University, \\ Rivne, Ukraine \\ ORCID: 0000-0001-9901-0337 \\ e-mail: anella.anella77@gmail.com \\ Olena VEREMCHUK, \\ Ph.D in Philosophy, \\ Associate Professor at the Department of \\ Philology and Social Communications, \\ Mukachevo State University, \\ Mukachevo, Ukraine \\ ORCID: 0000-0003-2514-8733 \\ e-mail: overemchukpopchuk@gmail.com
}

\section{MULTICULTURAL APPROACH TO PROFESSIONAL TRAINING OF HIGHER EDUCATION PROFESSIONALS}

Abstract. The article is devoted to the problem of the multicultural education, which has become a global necessity, a specialized form of teaching, which requires a differentiated approach and reforming of the educational 
process based on the positions of equality. The scale of changes under the influence of the globalization demands a significant increase in the educational level of the population as a whole. It demands a high-leveled training of the specialists, who are able to work in conditions of ethnic and cultural diversity based on the equal rights of national majorities, ethnic and cultural minorities and who support the cultural pluralism. The actualization of modern education occurs within the educational process while building the relationships that are grounded on the feeling of self-esteem. It should help people construct their own cognitive space based on coexistence, cooperation, ethics, mutual understanding and find tolerant and compromise solutions of the problems and conflicts.

Nowadays in order to be academically competitive the institutions of higher education have to modernize the educational programs, methods and forms of education, which would rest on the balance of cognitive growth of students, expand of their creative skills and instilling the students an understanding about the viability of society under the condition of ability to live and work together and to respect other cultures.

The higher educational institutions find their task in the formation of a multicultural personality through a system of activities, which help to participate in a multicultural environment and are: putting the individual in a multicultural educational environment, taking part in cultural practices, full-time and online learning in foreign universities etc. In the context of the competence approach in the educational process the multicultural competences should be considered as a component in the forming of the professional qualities of the student.

Key words: multicultural education, higher education, multicultural environment, educational process, online learning.

Постановка проблеми. У сучасному глобальному просторі, де стрімко зростають взаємозв'язки між державами та націями та який насичений проблемами, що пов'язані із правами людини, безпекою життєдіяльності, екосистемами та використанням національних ресурсів, заклади вищої освіти є своєрідним бекграундом для розвитку демократичних суспільств, підготовки спеціалістів для вирішення проблем, від яких залежить подальший прогрес людства. Масштабність змін під впливом глобалізації вимагає значного підвищення освітнього рівня населення загалом і підготовки спеціалістів, здатних працювати в умовах етнічної та культурної різноманітності на основі рівності прав національної більшості, етнічних і культурних меншин та підтримувати культурний плюралізм. Мультикультурна освіта стає глобальною необхідністю, спеціалізованою формою навчання, що грунтуючись на позиціях рівності, потребує диференційованого підходу у форматуванні навчального процесу 3 метою подолання мовних та культурних бар'єрів, усунення міжнаціональних суперечностей.

Аналіз наукових досліджень і публікацій. Для широкого наукового розуміння трактування поняття мультикультуралізму актуальним є звернення до праць М. Вебера, М. Вівйорки, К. Калхун, У. Кімліки, Ч. Кутакаса, Ч. Тейлора та ін. Концепції мультикультурної освіти розглядаються у працях К. Беннета, Д. Бенкса, П. Горскі, Е. Кіма та ін. Мультикультурні педагогічні програми досліджували К. Мок та В. Мейсан. Г. Поммерін характеризував полікультурну освіту як педагогічну відповідь на реальність мультикультурного суспільства, як діяльність, орієнтовану на ініціювання інноваційних процесів.

Праці українських науковців С. Когут, В. Кузьменко, Г. Левченко О. Сухомлинської, І. Соколової, Л. Хомич та ін. присвячені вивченню передумов практичного запровадження полікультурної освіти в Україні. Oсобливості становлення полікультурної освіти в Україні є об'єктом дослідження у публікаціях Р. Агадулліна, В. Асаєва, Ю. Безух, Я. Гулецької, О. Калакури та ін.

Метою статті є дослідити особливості використання мультикультурного підходу до навчального процесу у закладах вищої освіти.

Виклад основного матеріалу дослідження. Для сьогочасного світу глобалізація та інтеграція є тими моделями розвитку цивілізації, що посилюють та уособлюють тенденції до глобальних змін у культурному, економічному, політичному просторі, змінюють етнокультурну картину держав, актуалізуючи мультикультуралізм як ідею та завдання гармонійного існування полікультурного суспільства. Орієнтація мультикультурної моделі на збереження та розвиток культурної самобутності національних меншин створює умови для формування мультикультурної особистості у відповідності до культурного розмаїття сучасного світу, зокрема шляхом мультикультурної освіти.

Незважаючи на зростаючу критику ідеології мультикультуралізму з боку багатьох учених, мультикультурний простір, мультикультурне середовище та мультикультурна освіта є об'єктивними умовами існування країн та розвитку цивілізаційних процесів. Критикуючи наслідки невдалої мультикультурної політики у США та деяких країнах Європи, не можна не зважати на позитивні сторони іiї реалізації в освітньому середовищі. Мультикультурна освіта - це підхід до викладання та навчання, який базується на демократичних цінностях, що утверджують культурний плюралізм у культурно різноманітних суспільствах у їх взаємозалежності. Поняття «мультикультурна освіта» обумовлене як кількісними (міграція населення), так і якісними (зростання національної самосвідомості, обумовлене збереженням і розвитком етнічних культур) змінами в демографії багатьох країн (Clark: вебсайт, 2018).

Життєздатність та ефективність мультикультурної освіти базується на підході толерантності щодо рівних можливостей отримання освіти та маркується можливостями обмінюватися культурними цінностями, традиціями, поглядами, мовою у процесі навчання. Такі підходи дозволяють набувачам освіти здобути знання щодо моральних цінностей інших культур та розширити можливості професійного зростання й отримання досвіду в інших країнах. Мультикультурна освіта означає «освіту, що навчає людей здатності цінувати різні культури, які встановлені в традиційному суспільстві, приймати еволюцію в контакті з цими культурами, i ця різноманітність може стати надбанням, що збагачує власне культурне, соціальне та економічне життя» (Pavalache-Ilie, Voinea, Unianu: вебсайт, 2014). 
Освіта, більше ніж будь-коли раніше, запитувана на підготовку людини щодо вирішення завдань майбутнього у його невизначеності і можливість досягати поставлених цілей, що вбачається у відкритості та гнучкості навчального процесу, навчанні толерантності і як результат - вмінні жити разом у реальному культурному розмаїтті.

Сучасний рух у бік більш відкритих і демократичних суспільств об'єктивував потребу в навчанні, що виходить за рамки навчального плану і фактичних знань, котрі традиційно передаються у процесі навчання. Мультикультурна освіта, базуючись на принципі освітньої справедливості, забезпечує усунення перешкод для освітніх можливостей студентів із різних культур, створює умови для вдалої інтеграції у полікультурне середовище, зокрема освітнього простору країни, де вони навчаються.

Актуалізація сьогочасної освіти відбувається у царині побудови відносин на платформі самоповаги і відчуття власної гідності з метою допомогти людині конструювати власний когнітивний простір на основі співіснування, співпраці, етичних норм, взаєморозуміння і толерантного, компромісного вирішення проблем та конфліктів.

Мультикультуралізм в Україні, зазначає О. Гуренко, має стати однією з новітніх освітніх стратегій, що визначатиме якісно нові засади організації освітнього процесу, характер викладу дисциплін й методику позааудиторної та виховної роботи. Головна мета мультикультурної освіти - формування особистості, вільної від негативних етнокультурних стереотипів, яка володіє розвинутим почуттям розуміння інших культур і поваги до них, вміє жити в мирі й злагоді з людьми будь-яких національностей і віросповідань, а отже, $є$ готовою до творчої життєдіяльності в соціокультурному соціумі (Гуренко, 2009, с. 95).

Закладам вищої освіти для того, щоб бути академічно конкурентоспроможними, необхідно модернізувати освітні програми, методи та форми навчання, що грунтуватимуться на балансі пізнавального зростання, підвищення творчих навичок та прищеплення студентам розуміння про життєздатність суспільства за умови вміння жити й працювати разом, поваги та прихильності до інших культур.

У Білій книзі з міжкультурного діалогу наголошується, що заклади вищої освіти відіграють важливу роль у розвитку міжкультурного діалогу завдяки освітнім програмам як у ролі суспільних акторів у широкому розумінні цього слова, так і того місця, де міжкультурний діалог розвивається на практиці, де потребується проведення наукових розробок у галузі міжкультурних знань, а також звернення до таких аспектів, як «учитися жити разом» та присутність культурного розмаїття в усіх освітніх процесах (Біла книга 3 міжкультурного діалогу «Жити в гідному суспільстві як рівні», 2010, с. 35).

На думку А. І. Богданової, будь-яка освітня установа являє собою самоорганізовану систему, що накопичує і використовує свій досвід, свою культуру як індивідуальний конструкт кожного учасника освітнього середовища, так і всього освітнього закладу загалом. За цієї умови середовище кожного освітнього закладу є перетином взаємодіючих субкультур (різновікових, різнопрофільних, різносоціальних тощо) як структурних одиниць культури. Дослідниця зазначає, що таке освітнє середовище сприяє успішній інтеграції особистості у національну та світову культуру, формує як власне етнічну, так і загальнонаціональну самосвідомість індивіда (Богданова, 2011, с. 113).

Культурна стратегія розвитку закладів вищої освіти має полягати в організації системної діяльності, спрямованої на створення мультикультурного освітнього середовища, у якому формування мультикультурної особистості студента буде відбуватися не тільки через мультикультурний простір закладу вищої освіти, а й через залучення до участі у культурних практиках України та зарубіжних країн, через вебсемінари, онлайн-курси тощо. У контексті компетентнісного підходу до освітнього процесу мультикультурні компетентності мають розглядатися як складова формування професійних компетентностей студента.

Трансформація освітніх програм повинна відбуватися із включенням дисциплін мультикультурного дискурсу, які надаватимуть знання про історію та зв'язки своєї та інших культур, зокрема регіональних, знання у царині міжкультурної комунікації, навички міжкультурної взаємодії, відображатимуть життя поліетнічного суспільства та внесок у його розвиток етнічних меншин. Саме вивчення унікальної історії тієї чи іншої країни, формування матеріальної та нематеріальної культурної спадщини, культурний плюралізм сприяють вибудові в студентів більш широкого, складного та витонченого світосприймання, формують національну ідентичність, створюють умови для розвитку продуктивного суспільства.

Мультикультурний підхід до освіти об'єктивує звернення до холістичної освіти, мета якої полягає у підтримці співробітництва та взаємоповаги учасників навчального процесу, підтримці бажання постійно розширювати свій кругозір, пізнавати себе та навколишній світ, відкривати та розвивати свої здібності, бути відкритим для змін. Основним принципом та умовою дієвої холістичної освіти є поєднання емоційного, естетичного, творчого потенціалу всіх учасників навчального процесу як для надання, так і набуття знань.

Вища освіта - це канал трансляції культурних цінностей, що надає можливості для формування суб'єкта в конкретному суспільстві, який усвідомлює цілі власного розвитку та гармонізує їх із розвитком соціуму. Забезпечити формування такої особистості можна лише на основі нової холістичної парадигми освіти, що перетворює процес навчання та виховання із суб'єкт-об' єктного в суб'єкт-суб'єктний інтерактивний акт, вирівнює позиції студента та викладача, коли недостатньо тільки передати знання, а потрібно розкрити процес його народження (Шульга, 2015, с. 84).

Вирішення проблем трансформації та модернізації вищої освіти на принципах мультикультуралізму тісно пов'язане із використанням сучасних інформаційних технологій. Програмно-технічні засоби, що використовуються у навчанні переформатовують освітній процес, відкриваючи перспективи дистанційного навчання у зарубіжних університетах (відкриті університети, віртуальні університети), які пропонують онлайн-курси, 
онлайн-конференції, вебінари. Однією із форм, що сприяє досягненню цілей мультикультурного навчання, $\epsilon$, для прикладу, синхронні та асинхронні дискусії на онлайн-курсах, що базуються на створенні умов для надання студентам часу обміркувати свої відповіді та запитання. Багатолінійні діалоги між усіма учасниками (студенти та викладачі) надають можливість пропонувати теми дискусій, ідеї, створювати умови співпраці, що сприяє розвитку дослідницького, критичного, інноваційного та креативного мислення. Багатонаціональний контингент освітнього середовища онлайн-навчання сприяє розвитку суспільних зв'язків та міжкультурних відносин.

Т. Ілієва зазначає, що за допомогою багатонаціональних онлайн-курсів студенти можуть розвивати свої навички та покращувати власне розуміння, спілкуючись зі своїми однолітками. Культурне розмаїття та обізнаність допомагає тим, хто навчається в інтернеті, відчувати впевненість у тому, хто вони і що можуть запропонувати. Вони розуміють, що їх унікальний досвід і таланти підуть на користь групі загалом. Дослідниця наводить основні переваги полікультурного середовища: зростання розуміння та поваги до культурних відмінностей, додаткові творчі стимули в результаті впливу різних ідей, вивчення або зміцнення другої чи третьої мови, заохочення взаєморозуміння та толерантності між групами, підвищення допитливості завдяки різноманітності (Ilieva: вебсайт, 2018).

У сучасну модель мультикультурної освіти органічно вбудовуються інтернет-технології, пов'язані з використанням віртуальних світів. У мультикультурному онлайн-навчальному середовищі віртуальна екскурсія репрезентує та розширює культурно-освітній простір, встановлює зв'язок між культурами та студентами, які «відвідуючи» бібліотеки, музеї, художні галереї, артцентри, архіви, парки, історичні місця, «знаходяться» в автентичному середовищі.

Вагомою умовою для успішного мультикультурного навчання є знання студентами однієї або більше іноземних мов. Згідно з вимогами навчальної програми студент повинен засвоїти іноземну мову такою мірою, щоб уміти аудіювати, говорити, читати і писати. Мова $€$ дієвим інструментом у міжособистісному спілкуванні у полікультурному суспільстві. За визначенням В. А. Комарницької, мова - це інструмент культури, що формує особистість людини, яка саме через мову сприймає менталітет, традиції і звичаї свого народу, а також специфічний культурний образ світу (Комарницкая, 2009 , c. 14-15]. Важливим чинником розвитку професійних компетентностей майбутнього фахівця $є$ інтеграція іноземної мови із фаховими навчальними дисциплінами, як основа для набуття студентами додаткових фахових знань та спілкування у предметній площині обраного фаху з представниками інших культур.

Висновки. Мультикультурна освіта, використовуючи різноманітні ресурси, сприяє когнітивному та особистісному розвитку студента, підвищує творчі навички вирішення проблем через різні точки зору. Вивчення історії культур зменшує стереотипність та упереджене ставлення у взаємодії з їх представниками, збільшує позитивні стосунки завдяки досягненню спільних цілей, повазі, вдячності та прихильності.
Мультикультурна освіта має довгостроковий ефект, оскільки студенти, які навчилися цінувати свою культуру та культурне різноманіття, сприятимуть розвитку суспільства на принципах рівності та справедливості.

Перспективи подальших досліджень. Загальносвітові тенденції глобалізації та орієнтація України на інтеграцію в європейське та світове співтовариство вимагають переосмислення сутності та змісту вищої освіти. Майбутній фахівець повинен отримувати академічні та професійні знання, знання та навички міжкультурних взаємовідносин. Оскільки мультикультурна освіта є глобальною необхідністю, спеціалізованою формою навчання, що грунтується на позиціях рівності, організація та формування навчального процесу має розглядатися через призму міжнаціональної співпраці та гармонізації міжетнічних відносин.

\section{СПИСОК ВИКОРИСТАНОЇ ЛІТЕРАТУРИ}

Clark, D. (2018). A Call for Multiculturalism in Higher Education. Diverse: Issues In Higher Education. October 9. URL: https://diverseeducation.com/article/128883/ (дата звернення: 01.07.2021).

Pavalache-Ilie, M., Voinea, M., Unianu, E. (2014). Students' perception on the necessity of intercultural education in Romania. Procedia-Social and Behavioral Sciences 128. Pp. 447-452. URL: file://C:/Users/Work/ Downloads/students-perception-on-the-necessity-ofintercultural-education-in romania.pdf (дата звернення: 02.07.2021).

Гуренко, О. (2009). Полікультурна освіта в Україні: до сутності поняття. Збірник наукових праць Бердянського державного педагогічного університету. Серія «Педагогічні науки». Бердянськ: БДПУ. Вип. 1. C. 95-103.

Біла книга з міжкультурного діалогу «Жити в гідному суспільстві як рівні»= Белая книга о межкультурном диалоге «Жить в достойном обществе как равные» $=$ White Paper on Intercultural Dialogue «Living Together As Equals in Dignity» (2010) / ред.: I. І. Бабін, Б. С. Житнигор, С. Б. Житнигор та ін.; Всеукраїнська Академ. спілка спеціалістів проф. оцінки наук. досліджень і пед. діяльності. Одеса. 116 c. URL: https://shag.com.ua/ download/kniga-z-mijkuleturnogo-dialogu-jiti-razom-urivnosti-j-gidnost.doc (дата звернення: 01.07.2021).

Богданова, А. И. (2011). Поликультурная образовательная среда. Современные наукоемкие технологии. № 1. C. 113-115. URL: https://www.top-technologies.ru/ ru/article/view?id=26651 (дата звернення: 03.07.2021).

Шульга, Н. (2015). Холістичність - провідна тенденція розвитку освіти. Science and Education a New Dimension. Pedagogy and Psychology, III (37). Issue: 75. Pp. 84-87. URL: https://seanewdim.com/uploads/3/4/5/1/34511564/ shulga_n._holism_\%E2\%80\%93_the_leading_trend_of_ education.p.pdf (дата звернення: 01.07.2021).

Ilieva, T. (2018). Successful multicultural experience in a virtual classroom. Vedamo. July, 26. URL: https://www. vedamo.com/knowledge/successful-multicultural-experiencein-a-virtual-classroom/ (дата звернення: 05.07.2021).

Комарницкая, В. А. (2009). Содержание обучения иностранному языку студентов неязыковых специальностей в контексте поликультурности. Стандарти 
мовної освіти в аспекті інтеркультурної комунікації: матеріали I Міжнародної науково-практичної конференції. Мелітополь: МВП ЗІЕІТ. С. 14-15.

\section{REFERENCES}

Clark, D. (2018). A Call for Multiculturalism in Higher Education. Diverse: Issues In Higher Education. October 9. URL: https://diverseeducation.com/article/128883/ (data zvernennia: 01.07.2021). [in English].

Pavalache-Ilie, M., Voinea, M., Unianu, E. (2014). Students perception on the necessity of intercultural education in Romania. Procedia-Social and Behavioral Sciences 128. S. 447-452. URL: file:///C:/Users/Work/Downloads/ students-perception-on-the-necessity-of-intercultural-education-in romania.pdf (data zvernennia: 02.07.2021). [in English].

Hurenko, O. (2009). Polikulturna osvita v Ukraini: do sutnosti poniattia [Multicultural education in Ukraine: to the essence of the concept]. Zbirnyk naukovykh prats Berdianskoho derzhavnoho pedahohichnoho universytetu. Seriia "Pedahohichni nauky». Berdiansk: BDPU. Vyp. 1. S. 95-103. [in Ukrainian].

Bila knyha z mizhkulturnoho dialohu «Zhyty v hidnomu suspilstvi yak rivni» = Belaia knyha o mezhkulturnom dyalohe «Zhyt v dostoinom obshchestve kak ravnye» = White Paper on Intercultural Dialogue «Living Together As Equals in Dignity» (2010) / red.: I. I. Babin, B. S. Zhytnyhor, S. B. Zhytnyhor ta in.; Vseukrainska Akadem. spilka spetsialistiv prof. otsinky nauk. doslidzhen i ped. diialnosti. Odesa. $116 \mathrm{~s}$.
URL: https://shag.com.ua/download/kniga-z-mijkuleturnogo-dialogu-jiti-razom-u-rivnosti-j-gidnost.doc (data zvernennia: 01.07.2021). [in Ukrainian].

Bohdanova, A. Y. (2011). Polykulturnaia obrazovatelnaia sreda [Multicultural educational environment]. Sovremennye naukoemkye tekhnolohyy. № 1. S. 113-115. URL: https://www.top-technologies.ru/ru/article/view?id=26651 (data zvernennia: 03.07.2021). [in Russian].

Shulha, N. (2015). Kholistychnist - providna tendentsiia rozvytku osvity [Holisticity is a leading trend in the development of education]. Science and Education a New Dimension. Pedagogy and Psychology. III (37). Issue: 75. S. 84-87. URL: https://seanewdim.com/uploads/3/4/5/1/34511564/shulga n. holism_\%E2\%80\%93 the leading trend_of_education.pdf (data zvernennia: 01.07.2021). [in Ukrainian].

Ilieva, T. (2018). Successful multicultural experience in a virtual classroom. Vedamo. July, 26. URL: https:// www.vedamo.com/knowledge/successful-multicultural-experience-in-a-virtual-classroom/ (data zvernennia: 05.07.2021). [in English].

Komarnytskaia, V. A. (2009). Soderzhanye obuchenyia ynostrannomu yazыku studentov neiazykovykh spetsyalnostei v kontekste polykulturnosty [Content of teaching a foreign language to students of non-language specialties in the context of multiculturalism]. Standarty movnoi osvity $v$ aspekti interkulturnoi komunikatsii: materialy I Mizhnarodnoi naukovo-praktychnoi konferentsii. Melitopol: MVP ZIEIT. S. 14-15. [in Russian].

Дата надходження до редакиії: 29.06.2021 p. 